serum bilirubin. and further express their appreciation to .MUDr. A. Novik. CSc., and to Mrs. A. Kacerkovia for statistical calculations. and to the nursery statf of the Neonatal Unit (First Municipal Hospital) for collecting the urine of the neonites.

23. Requests for reprints should be addressed to: E. Talafant, M.D.. Depart

Copyright o 1977 International Pediatric Rescarch Foundation. Inc. ment of Medical Chemistry. Komensteho nim. 2, 6624.3 Brno (C)echoslovithia).

24. Reccived for publication August 26, 1976.

25. Accepted for publication December 21, 1976.

Pediat. Res. 11: 883-885 (1977)

Adolescence scoliosis

plasma

somatomedin

\title{
Plasma Somatomedin Activity in Normal and Scoliotic Children
}

\author{
(i. S. (i. SPLNCLER' AND) P. A. ZORAB
}

Paediatric Departme'nt, Cardiothoracic Institute, London, Lngland

\begin{abstract}
Summary
In a study of plasma somatomedin activity in childhood seoliosis a group of five patients with congenital scoliosis was found to have significantly lower plasma somatomedin levels compared with a group of 20 normal children. $A$ group of 52 patients with "idlopathic" scoliosis had normal plasma somatomedin levels. There is no apparent difference in the plasma somatomedin activity hetween the sexes, and no change in plasma somatomedin activity with chronologic age in these children, suggesting that normal adult somatomedin levels had been reached.

Speculation

In the rapid growth period of adolescence, plasma somatomedin activity is not raised. In scoliotic children many abnormal aspects of growth and metabolism have been reported, but somatomedin activity is normal. Presumably, therefore, either very small changes in somatomedin activity will produce a stimulation of growth and metabolism or the responsiveness of the target tissues is altered during periods of growth and, perhaps, in scoliosis. Children with congenital scoliosis have low plasma somatomedin activity, which is in keeping with the general impression that they are smaller than normal children of a similar age. Further endocrinologic and biochemical studies in scoliotic children may help elucidate the cause of "idiopathic" scoliosis.
\end{abstract}

Scoliosis is at condition which is closely associated with growth. and it is, therefore, inferesting that it wats not until 1972 that a study was made of the serum growth hormone levels in scoliotic patients (7). It is now known that the growth hormone molecule does not directly affect growth and metabolism of eells, and its action at the cellular level is mediated by somatomedin (1). (The generic name somatomedin is used throughout this paper rather than referring to specific somatomedins.)

One of the major actions of somatomedin is to stimulate the synthesis of chondroitin sulfate (11). It also stimulates the rate of cartilage cell proliferation in growth plates (4).

It has been suggested that "uncoiled" height (1.3) is greater in scoliotic children than in normal children, and that there is also a relative lengthening of the anterior components of the spine (vertebral bodies and dises) compared with the posterior components (neural arches and interspinous ligaments) (10). It hats been postulated that this is the cause of the vertebral rotation associated with the rapid rate of trunk growth during the adolescent growth spurt in scoliosis.

During the adoleseent growth spurt, the rate of spinal and pelvic growth is increased, ats in the interstitial cartilage growth in the vertebral plates and iliac crest cartilage. The galactosatmine concentration of the iliac crest cartilage is also increased (9), and is higher in scoliotic iliac crests than in normal children (s).

All these dissimilarities between scoliotic and normal children suggest that there maty be increased growth hormone and plasma somatomedin activity levels in the plasma of scoliotic children. It has been reported that "idiopathic" scoliotic children (those with spinal curvature of unknown origin) have normal growth hromone levels (7). This paper reports our findings on plasma somatomedin activity in scoliosis.

\section{MATERIALS AND METHOUS}

Plasma somatomedin activity was estimated in 20 normal English children, 25 French scoliotic children, and 32 English scoliotic children, from whom or from whose parents informed consent was received. The normal children were all healthy. nonhospitalized volunters within the age range of $10-19$ years. ()ne of the French children had congenital scoliosis whereas all the others had idiopathic scoliosis. The group of English scoliotic children comprised: + with infantile idiopathic scoliosis (0)-3 years of age when first diagnosed), 6 with juvenile idiopathic scoliosis (4-9 years). 15 with adolescent idiopathic scoliosis (1016 years), 4 with congenital scoliosis, and 3 others. All of the scoliotic children were within the age range of 9-18 years.

Blood was taken from each of these subjects before $9: 30$ in the morning after an overnight fast, and before any strenuous exercise. The blood was collected by a standardized procedure to reduce variations due to diet, sleep and exercise (all of which have been shown to alter growth hormone levels). as well as diurnal variation in plasma somatomedin activity levels. The blood was collected in heparinized tubes and the plasmat separated. frozen in Cardice. and kept at $-300^{\circ}$ until assayed. All plasma samples were frozen within 2 hr of venipuncture. To negate the possibility of any alteration in growth hormone levels 
because of wound healing, blood was taken from all patients before any surgical treatment.

Plasma somatomedin activity was estimated using the porcine costal cartilage bioassay of Van den Brande and Du Caju (12) with minor modifications. All plasma samples were compared with a pooled standard reference plasma collected from 30 healthy young adult volunteers. The potency ratios and their fiducial limits, as compared with the standard reference plasma, were calculated for each plasma sample according to standard, parallel line, bioassay statistics (3).

\section{RESULTS}

The plasma somatomedin activity of the scoliotic patients was compared with that of normal children (Table 1). No significant difference was observed. There was also no significant difference between the French and the English scoliotic patients.

There was no apparent difference in the plasma somatomedin activity between the sexes either as a whole, or in the case of the normal and patient groups individually (Table 2). There was also no apparent change in plasma somatomedin activity with chronologic age in the normal children (Table 3), suggesting that normal adult somatomedin levels had already been reached.

Patients with congenital scoliosis were found to have significantly lower plasma somatomedin levels compared with normal children; however, patients with idiopathic scoliosis were found to have normal plasma somatomedin levels (Table 1 ).

Three children with abnormal plasma somatomedin levels were found among those with scoliosis. Two of these patients had idiopathic scoliosis and a low plasma somatomedin activity, although the dose-response lines in both cases were parallel to the standard. One patient was an English boy of 15 years who had a potency ratio of $0.30(0.096-0.528)$ on admission to the hospital. The other patient was a French girl aged 12 years who had a potency ratio of $0.25(0.001-0.728)$. A girl referred from South Africa with congenital scoliosis also had a curious somatomedin level. This child was well below, the third centile for height and weight, being only 36 inches tall and weighing 22 pounds at 5 years of age. Her somatomedin potency, on a single sample only, was measured at $1.62(1.044-2.951)$. This is well above

Table 1. Comparison of plasma somatomedin activity in normal and scoliotic children

\begin{tabular}{|c|c|c|}
\hline (No. of patients) & $\begin{array}{l}\text { Mean } \mathrm{PR}^{1} \pm \\
\text { SD }\end{array}$ & t-test vs. normal \\
\hline Normal (20) & $1.003 \pm 0.295$ & \\
\hline Total scoliotics (57) & $0.888 \pm 0.299$ & n.s. \\
\hline English scoliotics (32) & $0.950 \pm 0.367$ & n.s. \\
\hline French scoliotics (25) & $0.851 \pm 0.203$ & n.s. \\
\hline \multicolumn{3}{|l|}{ "Idiopathic" scoliotics } \\
\hline Adolescent (15) & $1.051 \pm 0.234$ & n.s. \\
\hline Juvenile (6) & $0.899 \pm 0.569$ & n.s. \\
\hline Infantile (4) & $0.815 \pm 0.132$ & n.s. \\
\hline Congenital scoliotics (5) & $0.657 \pm 0.123$ & $0.01<P<0.02$ \\
\hline English vs. French scoliotics & & n.s. \\
\hline
\end{tabular}

1 Potency ratio.

Table 2. Sex difference in plasma somatomedin activity in adolescent children

\begin{tabular}{lccc}
\hline & \multicolumn{2}{c}{ Potency ratio \pm SD } & \\
\cline { 2 - 4 } & Female & Male & t-test \\
\hline Normal subjects & $0.927 \pm 0.354$ & $1.114 \pm 0.120$ & $\mathrm{n} . \mathrm{s}$. \\
English scoliotics & $1.004 \pm 0.372$ & $0.768 \pm 0.237$ & $\mathrm{n} . \mathrm{s}$. \\
French scoliotics & $0.860 \pm 0.201$ & $0.804 \pm 0.243$ & $\mathrm{n} . \mathrm{s}$. \\
& & & \\
All subjects & $0.924 \pm 0.304$ & $0.913 \pm 0.252$ & $\mathrm{n} . \mathrm{s}$. \\
\hline
\end{tabular}

Table 3. Plasma somatomedin activity in normal adolescent children

\begin{tabular}{|c|c|c|c|c|}
\hline \multicolumn{2}{|c|}{ Age } & \multirow[b]{2}{*}{ Sex } & \multirow{2}{*}{$\begin{array}{c}\text { Potency } \\
\text { ratio }\end{array}$} & \multirow[b]{2}{*}{ (95\% fiducial limits) } \\
\hline $\mathrm{Yr}$ & No & & & \\
\hline 10 & 9 & $M$ & 0.884 & $(0.597-1.272)$ \\
\hline 12 & () & $\mathrm{F}$ & 1.603 & $(0.875-4.260)$ \\
\hline 12 & 10 & $M 1$ & 1.239 & $(1.108-2.476)$ \\
\hline 13 & 2 & $M$ & 1.067 & $(0.863-1.322)$ \\
\hline 13 & 2 & $F$ & 0.599 & $(0.303-0.957)$ \\
\hline 13 & 7 & $M$ & 1.127 & $(0.891-1.4+1)$ \\
\hline 13 & 10 & $F$ & 0.568 & $(0.188-1.055)$ \\
\hline 14 & 1 & $\mathrm{~F}$ & 1.342 & $(0.964-1.975)$ \\
\hline 14 & 4 & $M$ & 1.032 & $(1.023-1.635)$ \\
\hline 14 & 4 & $\mathrm{~F}$ & 1.280 & $(0.804-1.332)$ \\
\hline 14 & 7 & $\Lambda$ & 1.128 & $(0.8(05-1.613)$ \\
\hline 15 & 1 & $\mathrm{~F}$ & 1.346 & $(0.887-2.238)$ \\
\hline 15 & 2 & $\mathrm{~F}$ & 0.704 & $(0.315-1.256)$ \\
\hline 15 & 10 & F & 1.117 & $(0.769-1.660)$ \\
\hline 16 & 1 & $\mathrm{~F}$ & 0.637 & $(0.206-1.245)$ \\
\hline 16 & 7 & $\mathrm{~F}$ & 0.803 & $(0.584-1.072)$ \\
\hline 16 & 10 & $M$ & 1.078 & $(0.866-1.3+8)$ \\
\hline 17 & 4 & $M$ & $0.5+2$ & $(0.084-1.862)$ \\
\hline 17 & 4 & $\mathrm{~F}$ & 1.106 & $(0.038-1.324)$ \\
\hline 19 & 4 & $\mathrm{~F}$ & 0.853 & $(0.631-1.130)$ \\
\hline
\end{tabular}

the normal limits for her age, and this may represent a case of "end-organ failure" in response to somatomedin.

The mean index of precision of the assays (s/b) was $0.17(n=$ $101)$ and the mean $g$ value was $0.14(n=101)$.

\section{DISCUSSION}

We have found no difference in somatomedin levels between normal children and children with idiopathic scoliosis. This correlates with the normal plasma growth hormone levels that have been reported in scoliotic children (7).

Increases in height (13), urinary hydroxyproline (14), galactosamine content of iliac crest cartilage (9), the hexose, hexosamine, and neuraminie acid content of the spinous processes (5). and serum chondroitin sulfate (6) have been reported in patients with scoliosis. Somatomedin is involved in all of these aspects of growth and metabolism. and it is thus surprising to find that somatomedin levels are normal in a group of patients who may otherwise have indications of increased somatomedin activity.

Du Caju and Van den Brande (2) reported that the plasma somatomedin activity in dysmorphic children (patients with multiple minor and major congenital malformations) was lower than in normal children. Because of their congenital malformation, congenital scoliotics are dysmorphic children of a particular type, and it is interesting to find that the congenital scoliotic patients studied here had low plasma somatomedin levels. At the , present time the reasons for this are obscure, but this evidence does fit well with the general impression that children with congenital scoliosis have a growth defect. Further endocrinologic and biochemical studies on scoliotic patients should help our understanding of the mechanisms involved in scoliosis.

\section{CONCLUSION}

Plasma somatomedin activity has been measured in normal and scoliotic children. Normal plasma somatomedin values for adolesent children have been reported. There is no apparent increase in somatomedin activity within this range and no sex difference was found. In a study of the plasma somatomedin activity in normal and scoliotic children, no differences were observed between the scoliotic children and their normal counterparts. This was surprising in view of the many abnormal aspects of growth and metabolism, previously reported in sco- 
iotic pationts, that might suggest an increased plasma somatonedin activity. In a limited study, a significant difference was sound between the plasma somatomedin activity of children with ongenital scoliosis and normal children.

\section{RIEFERENCISS AND NOTES}

1. Daughaday, W. H., Hall, K., Raben, M. S.. Salmon. W. D., Van den Brande J. L., and Van Wyk, J. J.: A proposed designation for the sulphation factor. Nature, 235: 107 (1972)

2. Du Caju. M. V. L., and Van den Brande, J. L.: Plasma somatomedin levels in growth disturbances. Acta Patediat. Scand., 62: 96 (1973)

3. Finney, D. J.: Statistical Methods in Biological Assay (Griffin, Londen, 1952).

4. Hall, K.. and Uthne, $K$.: Some biological properties of purified sulphation factor from human plasma. Acta Med. Scand., 19(): 137 (1971)

5. Kazmin, A. I., and Merhureva, R. V.: Aminopolyglycan sialo-, and glyeor protein content in the spine tissue of pattents with scoliosis (in Russian) Ortop. Travmatol. Protez. (Nonkva), 30: 20 (1969)

6. Kaz'min, A. I.. and Metkur'eva, R. V.: Role of glycosaminglycan metabolism disorders in the pathogencis of scoliosis (in Russian). Ortop. Travmatol. Protez (Moskva) 32: 87 (1971).

7. Misol. S., Ponseti, I. V., Samaan, N., and Bradbury, J. T.: Growth hormone bood leveis in pattents with idiopathic scoliosis. Clin. Orthop.. 821 $122(1972)$

8. Ponseti. I. V.: The pathogenesis of adolescent scoliosis. In (P. A. Zorab: Proceedings of a Sccond Symposium on Scoliosis: Causation, p. 60) (Livingstone, London, 1968).

9. Ponseti, 1. V., Pedrini-Mille, A., and Pedrini, V.: Histological and chemical analysis of human iliac crest cartilage. Calcif. Tissue Res..2: $197(1968)$.

10. Roaf, R.: The basic anatomy of scoliosis. J. Bone Joint Surg., 48B: 786 $(1966)$

11. Salmon, W. I)., and Datughaday, W. H.: A hormonally controlled serum factor which stimulates sulphate incorporation by cartilage in vitro. J. Lab. (lin. Med. 49: 825 (1957)

12. Van den Brande, J. L., and Du Caju, M. V. L.: An improved technique for measuring somatomedin activity in vitro. Acta Endocrinol. $75: 233$ (1974).

13. Willore, $S .: \wedge$ study of height, weight and menarche in girls with idiepathic scoliosis. Acta Orthop. Scand. 46: 71 (1975)

14. Zorab, P. A.. Clark. S., Cotrel. Y., and Harrison, A.: Bone collagen turnover in idiopathic scoliosis estimated from total hydroxyproline excretion. Arch. Dis. Childhood, 46: 828 (1971).

15. We are grateful to Mr. C. W. Manning. Mr. P. F. Milling, and M. Yves Cotrel for their help in the collection of hlood samples, and to D)r. J. L. Van den Brande for encouragement and technical advice.

16. This research was supported by the Welloome Foundation. The Brompton Hospital Research Fund, and St. Mary's Hospital, Paddington UK.

17. Requests for reprints should be addressed to: G. S. (j. Spencer, (irowth Section. Meat Rescarch Institute, Langford, Bristol (UK).

18. Received for publication November 3, 1976.

19. Accepted for publication January 27, 1977.
Blood volume growth hormone idiopathic short stature red cell mass

Russell-Silver dwarfism

\title{
The Effect of Growth Hormone Deficiency and of Growth Hormone Substitution on Blood Volume and Red Cell Parameters
}

\author{
OTWIN IINDERKAMP!:3H OTFRIID BUTENANDT, THERISE MADER, DIETER KNORR, ANI) \\ KLAUS P. RII:GEI.
}

Deparment of Pediatrics, University of Munich, Munich, Federal Republic of Germany

\begin{abstract}
Summary
Blood volume, plasma volume and red cell mass, red cell parameters, reticulocytes, serum iron, and total iron binding capacity were investigated. Fifty-nine growth-retarded children were studied: 27 children with idiopathic short stature (ISS) and 32 children with isolated growth hormone deficiency (GIID). Fifteen of the GHI) patients were studied before treatment and again 3-6 months after onset of treatment with growth hormone, 3 GIII) patients only before and 14 only during treatment. Blood volume, plasma volume, and red cell mass were significantly $(P<0.005)$ decreased by $15 \%$ in the untreated (GII) patients and were normal in the children studied during treatment with growth hormone compared with the values in ISS patients. In the 15 GHD patients studied before and during treatment, blood volume, plasma volume, and red cell mass increased by $17 \%$ to normal values $(P<0.0005)$ on treatment with growth hormone. No significant differences were demonstrable between values related to actual body weight and to corrected weight for height. Hematocrit, mean corpuscular volume, and reticulocytes remained unchanged. Serum iron and
\end{abstract}

total iron binding capacity were normal before treatment. Serum iron increased and total iron binding capacity decreased significantly during growth hormone substitution. In a pair of twins with Russell-Silver dwarfism and GHD, growth hormone increased blood volume, plasma volume, and red cell mass as in the other GHD patients. In another pair of twins with RussellSilver dwarfism without GHI), growth the hormone was without effect on blood volume.

\section{Speculation}

Our results of decreased blood volume and red cell mass in children with isolated GIID and the increase of blood volume and red cell mass during growth hormone treatment provide direct evidence that growth hormone is stimulating erythropoiesis. The less pronounced decrease of blood volume and red cell mass in our patients compared with the literature data obtained on panhypopituitary and hypophysectomized subjects may indicate that growth hormone, thyroxin, and other hormones act synergistically on erythropoiesis. 